\title{
Collecting Fees for Safekeeping of Collateral: Rules and Applications in the Contemporary Islamic Financial Institutions
}

\author{
Abdul Rahman Al-Saadi \\ Department of Islamic Finance, University of Bahrain, Bahrain \\ Received: 06/06/2020 \\ Accepted: 01/10/2020 \\ Published: 10/10/2020
}

\begin{abstract}
The study aims to examine the Shari'ah legality of whether pledgor or pledgee should take care of collateral (marhun) during the period of the loan. Moreover, the study seeks to provide possible applications for the pledge (rahn) and clarify Shari'ah rules for each application. Malaysian Islamic banks apply pledge products by offering loans (qardh hasan) to the customers and requesting gold assets as collateral against a loan. The banks charge safekeeping fees to keep the gold until the maturity date of the loan. This practice combines loan and sale contracts in a single transaction. Accordingly, the study seeks to evaluate this practice from an Islamic point of view. Islamic law categorizes loans under charity contracts while the sale is categorized under contracts of exchange (mu'awadhat). The nature of the two contracts is different. Therefore, the study examines categories that combine loans and contracts of exchange in one transaction. The results reveal that it is not permissible for the pledgee to charge fees higher than market fees for the keeping of collateral. Charging fees that are higher than the market price is considered riba. According to Shari' ah rules, any kind of benefit derived from a loan is riba and thus it is prohibited. However, charging fees that are comparable to the market price and cover the actual cost for safekeeping of collateral is permissible. According to Islamic Fiqh Academy resolutions and AAOIFI standards, Islamic banks may charge fees for safekeeping of gold collateral considering that fees should be to the market fees and should only cover actual expenses.
\end{abstract}

Keywords: Charitable Contracts, Contracts of Exchange, Pledgor, Pledgee, Rahn, Safekeeping Fees, Salaf wa Bai'

\section{Introduction}

Collecting fees for the safekeeping of collateral during the period of the loan is a controversial issue in Islamic Fiqh. Most of the Muslim scholars maintain that the pledgor (owner of collateral) should assume the cost of safekeeping. For example, if the pledgor provides an animal as collateral, he should maintain the cost of feeding, a place where the animal is kept and the guard who is protecting the animal. The majority based their opinion on hadiths and reasoning. According to hadith narrated by Sa'id bin Al-musayyeb, the prophet (Peace Be Upon Him) said that "the pledgee does not have the right to own the collateral if the pledgor does not fulfill his commitment. The pledgor has the right to enjoy gain realized from the collateral and, at the same time, bear the losses incurred" (reported by [3]; [5] and [17]). From a reasoning perspective, the majority argued that the collateral is an asset owned by the pledgor. As he is the owner, he should pay to keep his asset safe [2]; [12] and [6]).

On the other hand, the Hanifi school maintained that "the pledgor should assume expenses that keep the collateral itself in good condition. For example, if the pledgor pledges an animal as collateral, he/she should bear the expenses of feeding because food keeps the animal itself alive. On the other hand, the pledgee should assume other costs such as the place where the collateral is kept" [15]. The view of the majority prevails because collateral is owned by the pledgor. He is required, as a legal owner, to assume any cost to save the collateral during the period of the loan. Due to ownership, the pledgor is the only one can enjoy gain from the collateral on one hand, and on the other hand, he/she should bear losses that may occur.

Muslim scholars discussed the issue of collecting fees for safekeeping of collateral under the concept of (salaf wa bai') which means to combine loan and sale contracts in a single transaction. The creditor is willing to give a loan on the condition that the debtor should purchase an asset from the creditor at a price higher than the market price. The markup price is compensation to cover the cost of lending money. Under the concept of (salaf wa bai'), the present research will discuss the issue of charging fees for safekeeping of collateral that is pledged as a result of giving a loan. Although there is no sale contract is combined with the loan, the fees charged by Islamic banks are higher than fees charged by pawn shops. Therefore, the researchers believe that high fees in rahn products are used to

*Corresponding author: Abdul Rahman Al-Saadi, Department of Islamic Finance, University of Bahrain, Bahrain. E-mail: dralsaadi.bh@gmail.com 
cover the cost of lending money as the case in (salaf wa bai').

\section{Combining Loan and Sale Contracts in a Single Transaction}

Before deliberating on the discussion, there are two prophetic hadiths related to combine loan and sale in one transaction as follows:

a. Abdul Allah bin Umar narrated that the prophet (PBUH) said "it is not permissible to combine a loan with sale in one contract, stipulate two conditions in one sale, make a profit on something that for which you assume no liability and sell an object that you do not possess (narrated by [1]).

b. Abdul Allah bin Umar requested permission from the prophet to write his hadiths. The prophet allowed Abdul Allah to do so. Then Abdul Allah said: the first thing I wrote was a letter to Makkah people stating that "it is not permissible to stipulate two conditions in one sale, combine loan and sale in one transaction and sell something is not possessed by the seller" [9]. Muslim scholars agree that loan in hadiths refers to loan arises from lending money. Loan in Shari'ah law is categorized under charitable contracts such as hibah (gift) and wakalah (surety), while the sale is categorized under contracts of exchange (mu'awadhat) such as lease and salam. The Muslim scholars maintain that the concept of combination is not limited to combine loan and sale only but includes combining any charitable contract with any contract of exchange. [8] argued that it is not permissible to execute a contract of exchange with loan in one transaction. [19] proclaimed that "the meaning of the abovementioned hadiths indicates that it is not permissible to combine a charitable contract and contract of exchange in a single transaction because the objective of combination is to derive profit from contracts of exchange in return for giving charity. A charitable contract is a unilateral contract that aimed at a given charity (money or any kind of favour) without collecting advantage from the recipient".

\section{Categories of Combining Loan and Contracts of Exchange in a Single transaction}

There are three categories for combining loan and exchange contracts in one transaction namely, combining loan and contract of exchange with a stipulation in the documents to include both contracts in one transaction, combining loan and contracts of exchange in the favour of the creditor without stipulation in the document to include the two contracts, and combining loan and contract of exchange in one transaction without any stipulation in the document or favouritism.

\section{A. Combining Loan and Contract of Exchange with a Stipulation in the documents to include both Contracts in One Transaction}

The essence of this category is to conclude one contract with a stipulation to include either a loan in contract of exchange or vice-versa. There are two possible scenarios for this category as follows:

a. Favouritism: Two contracting parties, $\mathrm{A}$ and $\mathrm{B}$, agree to involve in a loan contract. A gives a loan to $\mathrm{B}$ with a condition in the loan contract that $\mathrm{B}$ should rent a property from $\mathrm{A}$ at a price higher than market price to enable A to gain a higher return to offset lending money. This scenario, according to the consensus of Muslim scholars, is prohibited. Selling an object with a condition in the sale contract that the buyer should take a loan from the seller is null and void. This view is of Imam Malik and Shaf' $i$ with no objection at all from followers of Maliki and Shaf' $i$ schools" [18]. Similarly, [10] argued that giving a loan with a condition in the contract that the creditor can utilize the collateral to derive tangible or intangible benefit makes the contract void. [19] took the same stand and argued that giving a loan with a stipulation that the debtor should rent an asset from the creditor at a price higher than the market price is unanimously not permissible.

b. A mere stipulation without favouritism: A gives loan to B with a condition in the loan contract that B should rent a property from A at a price equals the market price. Hanafi, Malaki, Shaf'i and Hanbali scholars agreed this scenario is not permissible. [16] claimed that all Muslim scholars unanimously declared such scenario null and void. [18] maintained that "it is not permissible to stipulate, in a loan contract, that debtor should rent creditor's house. It would be more sinful if the creditor stipulates that he/she will rent the debtor's house at a price lower than the market price. Overall, it is not permissible for the creditor to benefit from his loan by anyway". However, some Muslim scholars opined that it is permissible to combine loans and contracts of exchange in one transaction. This opinion is said to be a view of Ibn Taimiyyah (as mentioned in [11]). Al-Bilad bank in Saudi Arabia followed the latter opinion based on the following arguments:

1. The prohibition mentioned in the prophetic hadiths is interpreted in case that there is a kind of favoritism to bring more benefit for the creditor by imposing a condition to sell an asset to the debtor with a price higher than market price. If that is the case, then the creditor takes advantage of selling the asset at a higher price to cover the cost of giving a loan. Therefore, if the combining loan and sale bring no benefit to the creditor, the transaction is valid. [20] tried to explain the behaviour of the creditor who imposes a condition to combine loan and sale in one transaction by saying that "it seems that the purpose of the stipulation is to offset giving a loan by higher sale price to cover the cost of lending money. Under Islamic law, any loan that attracts any kind of benefit is considered as riba".

2. The prophet (PBUH) allowed a pledgee (the creditor) to utilize the collateral during the period of the loan. However, this utilization is strictly equal to the amount that creditor spends to keep the collateral in good condition. Abu Hurairah narrated that the prophet said: "It is permissible for pledgee (the debtor) to ride and milk livestock collateral during the period of the loan and he/she should bear expenses" [4]). According to the meaning of hadith, the creditor can take advantage of the collateral although the contract is a loan. It seems that taking advantage of the collateral is meant to compensate the creditor for giving a loan. The researchers believe that this view (combining loan and contract of exchange in one transaction) is acceptable. However, the derived benefit from the contract of exchange should not be higher than the market price.

B. Combining Loan and Contracts of Exchange in the Favour of the Creditor without Stipulation in the document to include the Two Contracts in One Transaction

Muslim scholars have two views regarding this category. First: Hanafi, Hanbali (including Ibn Taimiyyah) scholars maintained that it is not permissible to combine loan and contract of exchange for the favour of the creditor although it is not stipulated in the document to combine the two contracts in one 
transaction. The favour can be in the form of intangible or return. They supported their opinion arguing that the benefit that the creditor attains from the combination of the two contracts is riba. The creditor will give loans only if he ensures that the debtor will purchase an asset from him (the creditor) at a price higher than the market price. In fact, additional return from the sale contract is a compensation to cover the cost of lending the money. From the debtor perspective, he/she agrees to pay a price higher than the market price because he/she wants to fulfill the need for a loan. If there is no loan, the debtor will not accept buying an asset at a price higher than the market price. Therefore, even there is no stipulation to include loan and sale contracts in one transaction, the transaction is invalid because the creditor gains additional return due to lending money. According to Shari'ah, any kind of benefit derived from the loan is considered riba.

Second: Shaf'i scholars maintained that it is permissible to mutually (without stipulation) combine the two contracts even it is in the favour of the creditor [13]. The Shaf'i scholars founded their opinion on the argument that actions cannot be affected by intention which is hidden unless that intention is disclosed. [13] maintained that "no contract is judged based on something hidden. Every contract is valid unless contracting parties disclose an intention that is not in line with Shari'ah requirements, which nullifies the contract". [7] argued that "stipulating to combine loan and contract of exchange in one transaction invalidates the transaction. However, if the contracting parties mutually agree to execute the two contracts without stipulation, the transaction is valid". They based their opinion on the rule that "permissibility is the basic norm for any transaction". Furthermore, they proclaimed that prohibition in the hadiths narrated by Abdul Allah bin Umar is interpreted in the case that contracting parties write a condition in the document to combine loan and contract of exchange in one transaction. An intention is a hidden act that can be disclosed by writing. Therefore, if the contracting parties do not write a condition to combine loan and sale in the transaction's documents, the transaction is valid.

Having discussed the views of Muslim schools, the researchers believe that the first view is more acceptable. Writing a condition in the document of the transaction is not only the way to acquire knowledge about the real and ultimate objective of the contracting parties. Other understandable signs can be used to acquire knowledge about the real intention of the contracting parties. Oral and verbal actions also disclose the real intention. Under Islamic law, matters are judged by intention. Considering writing as the only way that can disclose intention may put people in hardship. Therefore, the real intention should be considered when examining the legality of such transactions to protect the right of all parties.

\section{Combining Loan and Contract of Exchange in One Transaction without any Stipulation or Favouritism}

The Fiqh debate over the validity of this category is obvious where Muslim scholars have two views. First, Hanbali scholars and some Maliki scholars declared that this category is forbidden. They founded their opinion on the hadiths narrated by Abdul Allah bin Umar as mentioned in section 3. They argued that these hadiths proscribe to combine loan and contract of exchange whether this combining emerged as a result of stipulation or favouritism.

Second, Hanafi, Malaki, and Shaf'i scholars proclaimed that combining loans and contracts of exchange is permissible.
However, the creditor should not achieve any benefit from this combination. They justified their position arguing that the basic norm of the transaction is permissibility unless there is a clear and valid justification that suggests otherwise. Islamic law forbids such combining due to possible advantages that the creditor could attain additional advantage or return. If the creditor cannot get an advantage, the transaction is valid.

In the view of the above discussion, the second opinion is prevails provided that: 1) contracting parties should not impose a condition to include the loan and contract of exchange in one transaction and 2) creditor should not obtain additional advantage or return.

\section{Collecting Fees for Safekeeping of Collateral}

In light of the above discussion, the relationship between pledgor (the debtor) and pledgee (the creditor) has two situations. First, the creditor collects fees higher than a market fee. Second: the creditor charges fees lower than market fees. In the first situation, collecting high fees is a kind of favouritism because the creditor gives loans and charge high safekeeping fees to cover the cost of lending money. The additional fees that the pledgee charges for safekeeping are riba because it is derived from money given as a loan. In the second situation, charging a comparable safekeeping fee is permissible in Islamic law. The fees will be used to maintain and protect the collateral while in custody during the period of the loan.

\section{Case Study: The Practice of Collateral (Rahan) in Malaysian Islamic Bank}

This section will examine the practical application of rahn in Malaysia. As one of the Islamic banking products used to provide micro qardh to low income earners, it is imperative to study the modus operandi to see if there is riba or not.

\section{A. Actual Application of Rahn in Islamic Banks}

The Islamic banks in Malaysia provide rahn products as one of their banking products. The customers who need liquidity approach the banks requesting for a loan (qardh hasan). Banks seek to please the customers by providing loan facilities. After acquiring approval, the customer is required to pledge gold as collateral to ensure that he/she can meet his obligation. Broadly speaking, all banks provide safekeeping services for customers and non-customers. It is not necessary to deposit gold with the bank as a result of taking a loan. The banks charge a standardized fee rate for safekeeping services. However, the fees that charge by Islamic banks are higher than fees charged by other pawn shops.

\section{B. Shari'ah Legality Basis for Rahn Product}

The legality of rahn product as practiced by Malaysian Islamic banks can be evaluated as follows:

1. It is a loan transaction with collateral that should be a pledge by the customer against the loan. From a Shariah perspective, it is permissible for the creditor to give a loan and request collateral to ensure that the debtor will settle the loan.

2. Shari'ah law does not allow the creditor to benefit from the collateral unless assuming the cost of utilizing it. After careful investigation, the banks receive the collateral (gold) to keep it without taking advantage of it, which is in line with the Shari'ah rule that required the creditor to avoid obtaining an advantage for 
the collateral.

3. The bank signs two contracts with the customer, loan contract and collateral safekeeping contract. In the practice, the bank combines the two contracts in one transaction. This practice can be categorized under category 1 . The bank collects fees that are comparable to fees collected from those who deposit gold without taking a loan from the banks. Furthermore, fees are standardized in the banking sector where all banks charge the same fee rates. From this perspective, there is no favouritism that arise as a result of collecting fees higher than market fees in the banking sector. However, when comparing fees in the banking sector and fees in the pawnshops, the banks charge fees higher than pawn shops. In this case, the issue of favouritism may arise because the banks collecting fees higher than market fees. After careful examination of the issue of favouritism in Malaysian Islamic banks, the researchers found that:

a. Most of the people prefer to pledge their gold with pawn shops because they (shops) charge low fees comparing to the fees charged by Islamic banks. This point supports the argument that there is a kind of favouritism for the favour of the banks because they charge fees higher than pawnshops fees.

b. The banks accept only gold as collateral against loans because it is easy for the banks to charge safekeeping fees. The banks, on the other hand, do not accept other kinds of collateral such as real estate because practically it is complicated to take real estate as collateral due to maintenance, security, quality, and value of the real estate. Therefore, the banks do not accept this kind of collateral because no benefit can be derived from the collateral.

c. Sometimes, and due to demand and supply and other economic factors, the value of gold decreases hugely by $20-30$ percent of its value. Usually, if the value of collateral decreases, the banks will request the customers to top up the value. However, although the value of gold is decreased, the banks do not request from the customers to top up the gold value. The banks prefer to keep collecting fees for safekeeping of the gold although the value is decreased. This may indicate that favouritism is working for the banks since they are collecting fees higher than fees collected by pawn shops. Having said that, the researchers adopted the view of Fiqh Academy and AAOIFI that states the banks should collect safekeeping fees equal to the fees collected by pawn shops. Also, the fees should only cover the actual cost of saving gold. Fiqh Academy (Hammad, 1997) has issued a resolution No. 13 stating that "it is permissible to collect fees for providing loan facilities to cover only the actual expenses". Similarly, AAOIFI (2017) has issued a standard No. 57 regarding gold and its trading parameters arguing that "it is permissible for the depository to charge fees for safekeeping the gold. The fees may be charged as a lump sum amount or as a percentage of the value of the deposited gold. If the gold is deposited as collateral against a loan borrowed by the depositor, the fees shall not exceed the actual cost incurred in safekeeping the deposited gold".

\section{Ethical issue}

Authors are aware of, and comply with, best practice in publication ethics specifically with regard to authorship (avoidance of guest authorship), dual submission, manipulation of figures, competing interests and compliance with policies on research ethics. Authors adhere to publication requirements that submitted work is original and has not been published elsewhere in any language.

\section{Competing interests}

The authors declare that there is no conflict of interest that would prejudice the impartiality of this scientific work.

\section{Authors' contribution}

All authors of this study have a complete contribution for data collection, data analyses and manuscript writing.

\section{References}

1. Abu Dawoud, Suliman. (n.d). Sunan Abi Dawoud. Edited by M. Abdul Hamid. Beirut: Al-Maktabah al-Asriyyah.

2. Al-Bahuti, Mansur. (n.d). Kashshaf al-Qina' 'an matin al-Iqna' Beirut: Dar al-Kutb al-Ilmiyyah.

3. Al-Baihaqi, Ahmad. (2003). Al-Sunan a-Kubra. Edited by M. A. Ata. Beirut: Dar al-Kutb al-Ilmiyyah.

4. Al-Bukhari, Muhammad. (2001). Al-Jami' al-Musnad al-Sahih alMukhtasar min amor rasul Allah sala Allah 'alih wa salam. [Book of rahn]. Edited by Muhammad Zuhair. Dar Tawq al-Najat.

5. Al-Daraqutni, Ali. (2004). Sunan al-Daraqutni. Edited by Sho'aib alArnaaout et. al. Beirut: Muassasah Al-Risalah.

6. Al-Dasuqi, Muhammad. (n.d).Hashiyat al-Dasuqi 'ala al-Sharh alKabeer. Beirut: Dar al-Fikr.

7. Al-Haitami, Ahmad. (1983). Tuhfat al-Muhtaj fi sharh al-Minhaj. Egypt: Al-Maktabah al-Tijariyyah al-Kubra.

8. Al-Hattab, Muhammad. (1992). Mawahib al-Jalil fi sharh mukhtasar khalil. N.d.

9. Al-Nasa'i, Ahmad. (2001). Al-Sunan al-Kubra. Edited by H. Shalabi. Beirut: Muassasah Al-Risalah.

10. Al-Nawawi, Yahya. (1991). Rawdhat al-Talibin wa 'Umdat alMufteen. Edited by Zuhari al-Shaweesh. Beirut: Al-Maktab al-Islami.

11. Al-Qari, Muhammad Ali. (2007). Tijarat al-Hamish. Journal of Fiqh Academy. Vol. 18. pp. 1-32.

12. Al-Ramli, Muhammad. (1984). Nihayat al-Muhtaj Ila sharh alMinhaj. Beirut: Dar al-Fikr.

13. Al-Shaf'i, Muhammad. (1990). Al-Umm. Beirut: Dar Al-Ma'rifah.

14. Hammad, Nazih. (1997). Bitaqat al-Itman ghair al-Mughatah. Journal of Fiqh Academy. Vol. 12. pp. 1341-1368.

15. Ibn 'Abdin, Muhammad. (1992). Rad al-Muhutar 'ala al-Durr alMukhtar. Beirut: Dar al-Fikr.

16. Ibn Abdul Barr, Yousuf. (1967). Al-Tamhid lima fi al-Muata' min alMa'ani wa al-Asaneed. Edited by Mustafa Ahmad \& Muhammad alBakri. Morocco: Ministry of Endowments and Islamic Affairs.

17. Ibn Hibban, Muhammad. (1988). Al-Ihisan fi taqrib sahih ibn Hibban. Collected by Ali bin Balban. Edited by Sho'aib al-Arnaaout. Beirut: Muassasah Al-Risalah.

18. Ibn Qudamah, Abdul Allah. (1968). Al-Mughni. Cairo: Maktabat alQahirah.

19. Ibn Taimiyyah, Ahmad. (1995). Majmu' al-Fatawa. Edited by Abdul Rahman Qasim. Saudi: King Fahd Complex for the Printing of the Holy Qur'an.

20. Ibn Taimiyyah, Ahmad. (1998). Bayan al-Dalil 'ala butlan al-Tahlil. Edit by Himdi al-Salafi. Beirut: Al-Maktab Al-Islami.

21. The Accounting and Auditing Organization for Islamic Financial Institutions (AAOIFI). (2017). Shari'ah Standards. Kingdom of Bahrain.

\section{Author Profile}

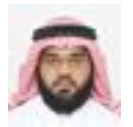

Dr. Abdul Rahman Al Saadi head of department of Islamic finance in the University of Bahrain. $\mathrm{He}$ is a senior consultant of Accounting and Auditing Organization for Islamic Financial Institutions (AAOIFI). 